\title{
Human Disturbance affects a Deciduous Forest Bird Community in the Andean Foothills of Central Bolivia
}

\author{
JOB ABEN, MARTIJN DORENBOSCH, SEBASTIAN K. HERZOG \\ ALFONS J. P. SMOLDERS and GERARD VAN DER VELDE
}

\begin{abstract}
Summary
Neotropical deciduous forests are threatened by anthropogenic activities and only a small area is protected against exploitation. In contrast to other Neotropical forest types, not much is known about the effect of habitat disturbance on deciduous forest bird communities. In the present study, we examine the effects of human disturbance on a deciduous forest bird community in the Andean foothills of Bolivia. Bird community composition was determined by means of point count surveys in three forest types, i.e. undisturbed deciduous and semi-deciduous forest, and disturbed forest habitat. Habitat disturbance was estimated indirectly by measuring vegetation structure variables in these forests. The effect of habitat disturbance was subsequently examined at bird community level (species richness, species abundance and diversity indices) and functional group level (habitat preference categories and foraging guild). Differences in community composition and reduced species abundance could clearly be related to habitat disturbance. However, results also indicated that sensitivity to disturbance varied among functional groups. Humid forest specialists showed the strongest response to habitat disturbance, predominantly bark-gleaning insectivores, canopy insectivores, understorey insectivores and ground-dwelling species, whereas dry forest specialists were not affected by disturbance. The present study suggests that anthropogenic disturbance negatively influenced the forest bird community in the investigated deciduous forest in Bolivia. This may indicate that conservation of both deciduous and semi-deciduous forest remnants is relevant for a diverse montane bird community in South America. Because various bird species typical of deciduous forests may also be able to survive in partly disturbed forests, conservation strategies should not only be focussed on the protection of pristine remnants but should also include secondary forest edge zones.
\end{abstract}

\section{Resumen}

Los bosques deciduos neotropicales están amenazados por actividades antropogénicas, y sólo una pequeña extensión se encuentra protegida de la explotación humana. A diferencia de otros tipos de bosques neotropicales, se sabe poco acerca del efecto de la alteración de hábitat sobre las comunidades de aves de bosques deciduos. En el presente estudio examinamos el efecto de la alteración humana sobre una comunidad de aves en un bosque deciduo en el pie de monte andino de Bolivia. Se determinó la composición de la comunidad de aves mediante conteos por punto en tres tipos de bosque, es decir bosque deciduo y semi deciduo no perturbado, además de bosque perturbado. La perturbación del hábitat en estos bosques fue estimada indirectamente por medio de la medición de variables estructurales de la vegetación. Subsecuentemente se examinó los efectos de la alteración del hábitat a nivel de la comunidad de aves (riqueza y abundancia de especies, índices de diversidad) y a nivel de grupos funcionales (categorías de preferencia de hábitat, gremios). Variaciones en la 
composición de comunidades y en la abundancia de especies se hallaron claramente relacionadas con la alteración del hábitat. Sin embargo los resultados también indicaron que la sensibilidad a la alteración del hábitat varía entre grupos funcionales. Los especialistas de bosque húmedo se caracterizaron por una mayor respuesta a la alteración del hábitat, sobre todo los insectívoros de corteza, del dosel, del sotobosque y especies del suelo. Por el contrario, los especialistas de bosque deciduo no se vieron afectados por la perturbación. El presente estudio indica que existe un impacto negativo de la alteración antropogénica sobre la comunidad de aves en el bosque deciduo estudiado en Bolivia. Esto indica que la conservación tanto de vestigios de bosque deciduo como de bosque semi deciduo es necesaria para mantener una avifauna andina diversa. Dado que muchas especies especialistas de bosque deciduo aparentemente pueden persistir en bosques perturbados, las estrategias de conservación no deberían enfocarse sólo en la protección de vestigios de bosque prístino, sino que también deberían incluir áreas de bosque perturbado y secundario.

\section{Introduction}

In contrast with tropical rainforests, tropical deciduous forests have received little or no attention with respect to ornithological research (Herzog and Kessler 2002) and habitat conservation (Sánchez-Azofeifa et al. 2005). However, tropical deciduous forests are among the most threatened ecosystems in South America (Janzen 1988, Bullock et al. 1995, Beissinger et al. 1996), and contain many range-restricted and threatened bird species (Stattersfield et al. 1998, BirdLife International 2000).

In the Neotropics, the largest tropical deciduous forest remnants are located in Bolivia (Parker et al. 1993, Perry et al. 1997). Here, they are extensively distributed in the southern lowlands and extend into the Andes in rain-shadowed intermontane valleys (Herzog and Kessler 2002). Because of the relatively high economic potential of these forests, most of them face strong anthropogenic disturbance throughout the Neotropics and only a small proportion of the total area is under some level of conservation (Sánchez-Azofeifa et al. 2005). As a consequence, deciduous forest bird communities are likely to be more threatened by ongoing deforestation compared to bird communities of tropical evergreen forests (Stattersfield et al. 1998, Achard et al. 2002). Whereas other studies have shown that deforestation and habitat disturbance negatively affected bird communities of various tropical forest types (e.g. Thiollay 1997, Woltmann 2003, Watson et al. 2004, Lee et al. 2004, Peh et al. 2005, Soh et al. 2006), this has never been investigated for bird communities of tropical deciduous forests in South America.

It has been shown that habitat disturbance does not affect all bird species within an assemblage equally. The response to disturbance of individual species may depend on their degree of habitat specialisation, with habitat specialists being more sensitive than habitat generalists (Canterbury et al. 2000, Petit and Petit 2003, Tejeda-Cruz and Sutherland 2005), and foraging guild (Thiollay 1997, Peh et al. 2005).

It has been suggested that bird communities inhabiting forests where natural disturbances occur frequently, may be pre-adapted to habitat disturbance and may therefore be more resilient to human-induced habitat disturbance (Mönkkönen and Welsh 1994, Schmiegelow et al. 1997). Consequently, it can be hypothesised that species typical of tropical humid forests will be affected differently by disturbance than species typical of dry forests, because of differences in natural disturbance regimes between these forest types (Andresen 2005). Compared to tropical evergreen forests, tropical deciduous forests experience a more distinct wet and dry season resulting in stronger temporal and spatial variation in forest structure. Therefore, despite clear negative effects of disturbance on bird communities in tropical evergreen forests, the effect of disturbance on bird communities in South American deciduous forests can be debated. Deciduous forests in the Andean foothills in central Bolivia provide good opportunities to investigate this conundrum. The natural forest configuration allows the comparison of bird communities between semi-deciduous and deciduous foothill forests and an anthropogenically disturbed deciduous forest. 
In the present study we report on the bird community composition of three contrasting deciduous forests in the Andean foothills of central Bolivia, and investigate the influence of human habitat disturbance by comparing bird communities between undisturbed semi-deciduous and deciduous foothill forests and anthropogenically disturbed forest habitat. The following questions are addressed in the present study: (I) What is the influence of habitat disturbance on deciduous forest bird community composition, species richness and abundance? (2) Can sensitivity of bird species to habitat disturbance be related to foraging guild and degree of forest habitat specialization?

\section{Methods}

Study area

The study area was located in the east Andean foothills in the department of Santa Cruz, Bolivia, $57 \mathrm{~km}$ south-west of Santa Cruz de la Sierra (Figure 1). Three forest sites were selected, two undisturbed and one disturbed site, between elevations of 1,000-1,350 $\mathrm{m}$ a.s.l. Both undisturbed sites were located within the boundaries of the Refugio Los Volcanes ( $18^{\circ} 06^{\prime} \mathrm{S}, 63^{\circ} 36^{\prime} \mathrm{W}$, Figure 1 ), a private nature reserve $\left(3 \mathrm{~km}^{2}\right)$ adjacent to Amboró National Park. The disturbed site $\left(18^{\circ} \mathrm{O} 7^{\prime} \mathrm{S}\right.$, $63^{\circ} 37^{\prime} \mathrm{W}$, Figure $\mathrm{I}$ ) covered the area $\left(3.3 \mathrm{~km}^{2}\right)$ between Los Volcanes and the small rural village of Bermejo. Estimated mean annual rainfall in Los Volcanes is $1,300 \mathrm{~mm}$ (Herzog and Kessler 2002). Mean annual precipitation at the Bermejo climatic station ( $900 \mathrm{~m}$ ) is $1,233 \mathrm{~mm}$ (19982004). Rainfall shows a strongly seasonal pattern. During the wet season from November to March (the austral summer), monthly means are well in excess of $100 \mathrm{~mm}$ (130-175 mm), whereas from May to September monthly means drop well below $100 \mathrm{~mm}$ (to a minimum of $17 \mathrm{~mm}$ in August). April and October represent transition periods with intermediate amounts of precipitation. Mean annual temperature at Bermejo is $23.7^{\circ} \mathrm{C}$ (2001-2004), with monthly maxima in October and January $\left(26.2^{\circ} \mathrm{C}\right)$ and a minimum in July $\left(19.9^{\circ} \mathrm{C}\right)$.

Because of the mountainous character of the region, forests experience large differences in exposure to solar radiation, resulting in spatial variation in forest structure, tree species composition and microclimate (i.e. deciduous and semi-deciduous forest). The dominant tree species of the study area in general were Pachystroma longifolium (Euphorbiaceae), Trichilia claussenii (Meliaceae), Parapiptadenia excelsa (Mimosaceae), Drypetes amazonica (Euphorbiaceae), Aspidosperma cylindrocarpon (Apocynaceae) and Chrysophyllum gonocarpum (Sapotaceae) (SKH et al. unpublished data). Deciduous forests in the study area were dominated by $T$. claussenii and P. excelsa, whereas semi-deciduous forests were dominated by P. longifolium and D. amazonica (SKH et al. unpublished data).

One undisturbed forest site was chosen in a semi-deciduous forest, whereas the second undisturbed site was chosen in a deciduous forest (distance between the centre of these two forest sites was $1.6 \mathrm{~km}$ ). The semi-deciduous forest was characterized by relatively low seasonal variation in forest structure and canopy cover, and contained ferns, vine-tangles, many epiphytes and moderate moss cover on trees. The deciduous forest experiences distinct seasonal variation in forest structure and canopy cover, and was characterized by a less complex forest structure with an open mid- and understorey, low ground herb cover, scarce epiphytes and very low moss cover on trees.

The disturbed forest site encompassed a mixed array of degraded habitats that approximately 50 years ago was part of a large area of pristine deciduous and semi-deciduous forests that was connected to the present primary deciduous forest where the undisturbed sites were located. It consisted of secondary forest, selectively logged primary forest remnants, and shrubland with few isolated larger trees. The area was criss-crossed by cattle trails. Distances from the centre of the disturbed forest to the centre of the deciduous forest and semi-deciduous forest were $2.8 \mathrm{~km}$ and 4.4 $\mathrm{km}$ respectively. Compared to the undisturbed forest sites, the disturbed forest was characterised by low densities of large trees, low canopy cover, high densities of young trees and high herbcover consisting predominantly of grasses. All three study sites were part of continuous habitat 


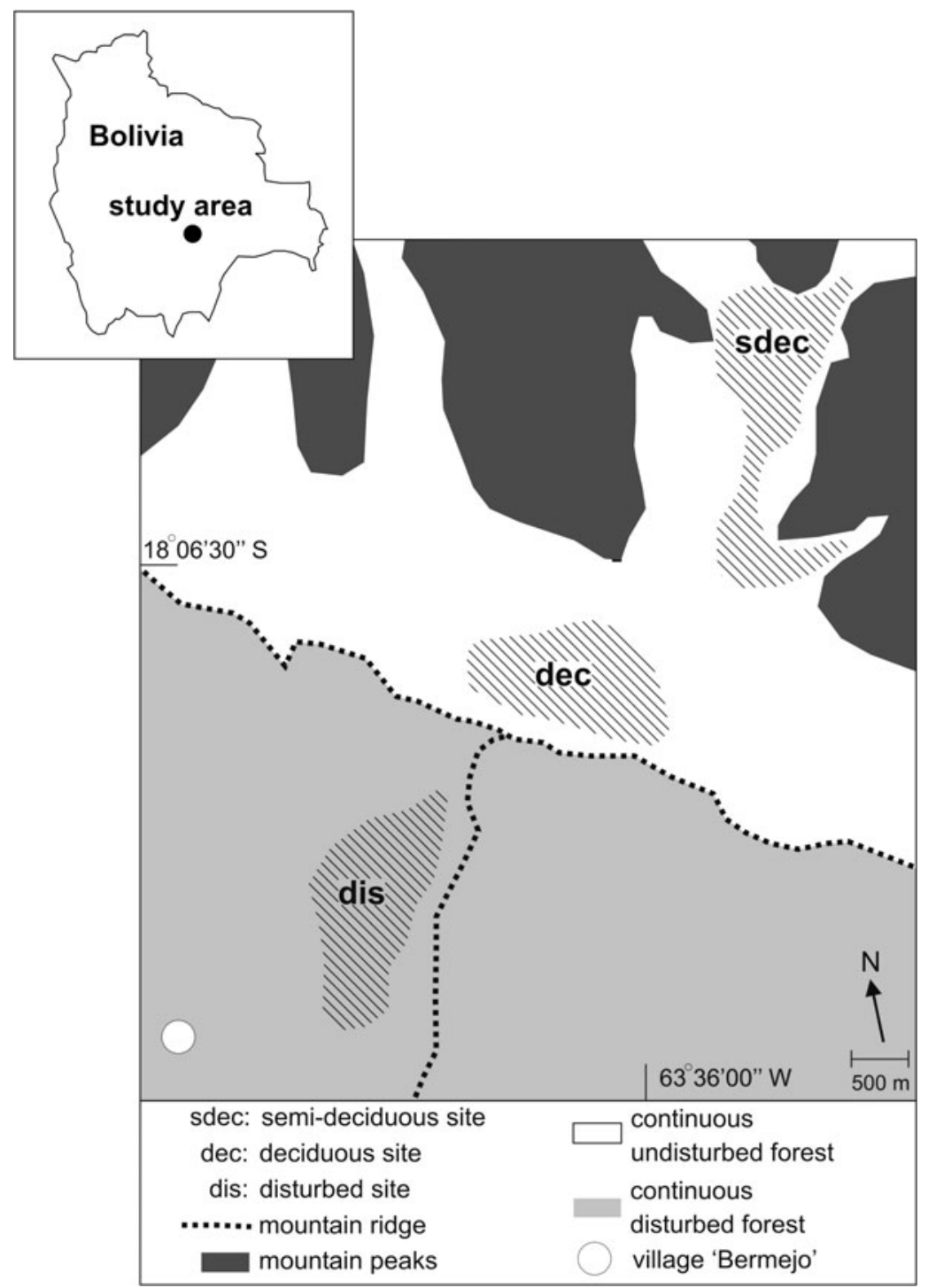

Figure 1. Study area showing the locations of the study sites. Count stations of each study site were located within the hatched areas. All three study sites were part of continuous habitats.

(either disturbed or undisturbed forest), and represented samples from large areas of forest rather than isolated patches in a heterogeneous landscape (Figure 1 ).

\section{Bird surveys}

Bird surveys were conducted using the point count technique because bird data collected by this method can be directly related to vegetation structure (Bibby et al. 2000). Bird data were collected from August to October 2005, which coincides with the start of the avian breeding season in the region (SKH unpublished data). To minimise observer bias, all surveys were carried out by JA after having familiarised himself with the local bird communities. 
To sample bird communities, 16 point count stations were selected in the semi-deciduous forest, 14 in the deciduous forest, and 17 in the disturbed forest. Within each study site, stations were chosen as randomly as possible given logistical constraints of steep mountain slopes. In the disturbed forest, stations were located close to cattle trails as shrubby areas often were impenetrably dense. To assure independence between point count stations, the minimum distance between stations was $250 \mathrm{~m}$. Every point count station was censused four times during the study period, and all censuses were conducted during hours of peak vocal activity (between $05 \mathrm{~h} 3 \mathrm{O}$ and $08 \mathrm{hoo}$ ), on days without strong wind or rain. To minimise the effect of time of day on species detection probabilities and possible seasonality during the research period, the order in which study sites and stations were censused was alternated. During a point count, all birds were recorded in a 12-min period within a 50-m radius of each station. Birds only flying over or through the point count area, or strictly nocturnal species were excluded from the study. The 12-min period was chosen based on results of a previous study in Los Volcanes (SKH unpublished data). Care was taken to avoid double counting of individuals. Sounds which could not be identified were recorded on a minidisk and compared with vocalizations on a CD-ROM (Mayer 200o) or identified by SKH.

\section{Vegetation sampling}

To investigate the relationship between vegetation structure and the presence or absence and abundance of bird species, a variety of vegetation structure variables were quantified within a 1o $\mathrm{m}$ radius of each point count station. It was assumed that a $10-\mathrm{m}$ radius correctly reflected the vegetation structure of the entire $50 \mathrm{~m}$ radius of a bird sampling plot. Vegetation variables were quantified by a single well-trained observer. For each point count station, the following variables were visually estimated: (I) \% of tree canopy cover (trees > Io m height); (2) canopy height (m); (3) \% of shrub cover (woody vegetation, height o-2 m); (4) \% of herb cover (non-woody vegetation, height $\mathrm{O}-1 \mathrm{~m}$ ); (5) total vegetation volume (TVV) of shrubs (height o-2 $\mathrm{m}$ ); and (6) TVV of understorey trees (height $0-5 \mathrm{~m}$ ). Additionally, the diameter at breast height (dbh) of all trees and saplings on the plot was measured, and trees were subsequently categorized in five diameter classes $(<2,2-10,10-20,20-40$, and $>40 \mathrm{~cm})$. Dead standing trees with a dbh $>10 \mathrm{~cm}$ were also counted. TVV of shrub and understorey trees was estimated following Peh et al. (2005) using a 5-m pole. The pole was divided into five sections of $1 \mathrm{~m}$ length and each section was further subdivided into $20 \mathrm{~cm}$ sections. The vegetation volume was subsequently derived by counting the number of leaf hits within a $5 \mathrm{~cm}$ radius of each $20 \mathrm{~cm}$ subsection of the pole, with the constraint that only one hit in each cardinal direction is allowed (maximum of four hits per subsection). After 10 random samples within the vegetation sample plot, the average of the readings was calculated and expressed as TVV. To assess a measure of vegetation structure heterogeneity of the three forest types, the mean coefficient of variance $(\mathrm{CV})$ was calculated of the continuous vegetation structure variables (mean dbh, number of trees with a $\mathrm{dbh}<2 \mathrm{~cm}$, percent canopy height and cover, percent herb and shrub cover, number of dead trees and vegetation volume indices).

\section{Data analysis}

To determine if sample effort was sufficient, species accumulation curves were computed for each forest type. Total species richness per forest type was estimated by using the non-parametric species richness estimator Chao 2, which is intended for tropical assemblages in which rare species predominate (Herzog et al. 2002). Because species richness is a function of abundance (as more individuals are sampled, more species will be recorded), species richness was compared between forest types by graphing individual-based rarefaction curves with number of species plotted as a function of the accumulated number of individuals (Gotelli and Colwell 2001; Colwell et al. 2004). Mao Tau $95 \%$ confidence intervals were plotted to draw conclusions about the differences in species richness between the three habitats. Abundances of individual bird species (based on 
the maximum number of individuals per count station recorded during the four surveys) were compared between the three forest types using Kruskal-Wallis tests, followed by a Games Howell post-hoc test.

EstimateS (Colwell 2005) was used to calculate Shannon diversity indices for each forest site. Two point count stations from the semi-deciduous forest and three from the disturbed forest were randomly excluded from this analysis to obtain equal sample areas. Additionally, EstimateS was used to calculate the abundance-based Jaccard estimator to quantify similarity in species composition between forest types and to assess a measure of species turnover within forest study sites (beta diversity), expressed as Jaccard dissimilarity values (dissimilarity $\hat{j}=1-$ similarity $\hat{j}$ ). This index is best suited for assessing compositional similarity between samples that differ in size (individual density), are known to be undersampled, or are likely to contain numerous rare species (Chao et al. 2005).

To analyse the spatial distribution of bird community composition in the three forest sites, a two dimensional ordination of all point count stations was conducted on $\log ^{10}$-transformed bird species abundance data in a correspondence analysis (CA) using CANOCO (Ter Braak 1995).

\section{Vegetation structure and bird species abundances}

To determine the effect of habitat disturbance on bird community composition, expressed as a relation between species abundances and vegetation structure variables, a canonical correspondence analysis (CCA) was performed on $\log ^{\mathrm{T}}$-transformed bird species abundance data and condensed vegetation variables per point count station using CANOCO (Ter Braak 1995). Variation in vegetation structure was condensed by performing a principal component analysis (PCA) on all vegetation structure variables per point count station prior to CCA. Factor scores of the four axes were subsequently entered as vegetation structure variables and used in the CCA. Length of gradient and suitability of using unimodal analyses (PCA and CCA) were checked prior to PCA and CCA by preliminary detrended correspondence analyses. A Monte-Carlo permutation test (500 random permutations) was used to assess if the relationships between vegetation structure variables and bird community composition were significant. CCA axis scores were rescaled using Hill's scaling method.

\section{Ecological traits}

To investigate if habitat preference and foraging guild affected sensitivity of bird species to disturbance, all species were classified $a$ priori into habitat categories and foraging guilds. Based on Herzog and Kessler (2002), bird species were assigned to the following habitat preference categories: (I) dry forest specialists (species primarily or exclusively inhabiting deciduous and semi-deciduous forest throughout their breeding range); (2) humid forest specialists (primarily inhabiting evergreen forest); (3) forest habitat generalists (species regularly found both in deciduous and evergreen forest); and (4) species of other habitat (essentially non-forest species). Secondly, all species were a priori assigned to the following foraging guilds (based on del Hoyo et al. 1992-2005, and Ridgely and Tudor 1989, 1994): (1) canopy insectivore (species primarily feeding on insects and other arthropods); (2) canopy frugi-granivore (species primarily feeding on fruit, seeds and other plant material); (3) canopy omnivore (species feeding on insects and fruits equally); (4) understorey insectivore; (5) understorey frugi-granivore; (6) bark-gleaning insectivore; (7) ground-dwelling species; (8) nectarivore (species primarily feeding on nectar); (9) carnivore (species primarily feeding on live vertebrate prey); (10) scrub insectivore; and (II) scrub frugi-granivore. Species with mixed diets were assigned to the category representing the major component of their diets. The distinguished habitat and foraging guilds are shown in Appendix.

Mean abundance per habitat category and foraging guild were subsequently compared between the three forest types using one-way ANOVA or Kruskal-Wallis tests followed by Tukey's and 
Games-Howell post-hoc tests, respectively. Independent sample t-tests were used to compare means of functional groups only present in two of the three forest types. Statistical analyses were performed using SPSS version 14.0 (SPSS, Inc., Chicago, USA).

\section{Results}

\section{Bird species diversity and communities}

During the surveys, a total of 115 bird species were observed. The lowest number of species was observed in the disturbed forest $(n=58)$, whereas higher numbers were found in the deciduous and semi-deciduous forest $(n=73, n=69$ respectively, Table 1$)$. Although rarefaction curves also showed lowest species richness in the disturbed forest, differences were not significant at the $95 \%$ confidence interval (data not shown). Compared to the undisturbed forests, 57 species were not recorded in the disturbed forest. However, the latter forest type accounted for the highest number of species $(n=24)$ exclusively observed in one of the three forest sites ( $n=17$ for the semi-deciduous forest, $n=14$ for the deciduous forest, respectively). Mean species abundance was significantly lowest in the disturbed forest (Kruskal-Wallis test, $\chi^{2}=28.11, P<0.001$, Table 1 ). Mean alpha diversity (Shannon-Wiener index) per count station was also lowest in the disturbed forest, whereas beta diversity (spatial turnover in species composition among within-habitat count stations) was highest in the disturbed forest (Table 1 ).

Estimated species richness (expressed as Chao 2) suggested that not all species were detected. However, species accumulation curves of each habitat type were approaching an asymptote, indicating that survey effort was sufficient to appropriately capture the species richness of the three study sites (data not shown).

Correspondence analysis clearly showed a spatial pattern in distribution of point count stations where three different bird communities reflected the habitat types (Figure 2). Point count stations of the semi-deciduous and deciduous forest clustered relatively close together indicating considerable overlap in bird communities, whereas the disturbed forest count stations formed an entirely separated and widely dispersed cluster. Community similarity values calculated by the abundancebased Jaccard estimator supported these results (Table 1 ), with species composition being most similar between the two undisturbed sites $(76 \%)$, intermediate between deciduous forest and disturbed forest $(56 \%)$ and lowest between semi-deciduous forest and disturbed forest (39\%).

\section{Habitat structure associations}

Human habitat disturbance was positively correlated with spatial habitat heterogeneity (expressed by the mean coefficient of variation of continuous vegetation structure variables per count station, see Table 1 ), and corresponded with highest beta diversity within the disturbed forest (Table 1 ).

Principal component analysis was performed on all vegetation structure variables to generate point count station factor scores for the four PC axes. These condensed vegetation structure

Table 1. Observed bird species richness (S), estimated species richness (Chao 2), total number of individuals $(N)$, Shannon-Wiener indices $\left(H^{\prime}\right)$, mean beta diversity $(\beta)$, mean coefficient of variation of all continuous vegetation structure variables $(C V)$, and mean individual density $(X n)$ at the three study sites $( \pm S D)$. Different letters indicate significant differences of $\mathrm{X} n$ between the three forest types (Kruskal Wallis test; $P<$ o.001).

\begin{tabular}{llllllll}
\hline Forest type & $S$ & $\mathrm{CHAO}_{2}$ & $N$ & $H^{\prime}$ & $\beta$ & $C V$ & $X n$ \\
\hline Semi-deciduous forest & 69 & 71.81 & 629 & 3.87 & 0.22 & 0.32 & $39.31(6.99)^{\mathrm{a}}$ \\
Deciduous forest & 73 & 78.57 & 574 & 3.90 & 0.11 & 0.38 & $41.29(9.39)^{\mathrm{a}}$ \\
Disturbed forest & 58 & 64.67 & 413 & 3.66 & 0.51 & 0.77 & $24.29(4.37)^{\mathrm{b}}$ \\
\hline
\end{tabular}




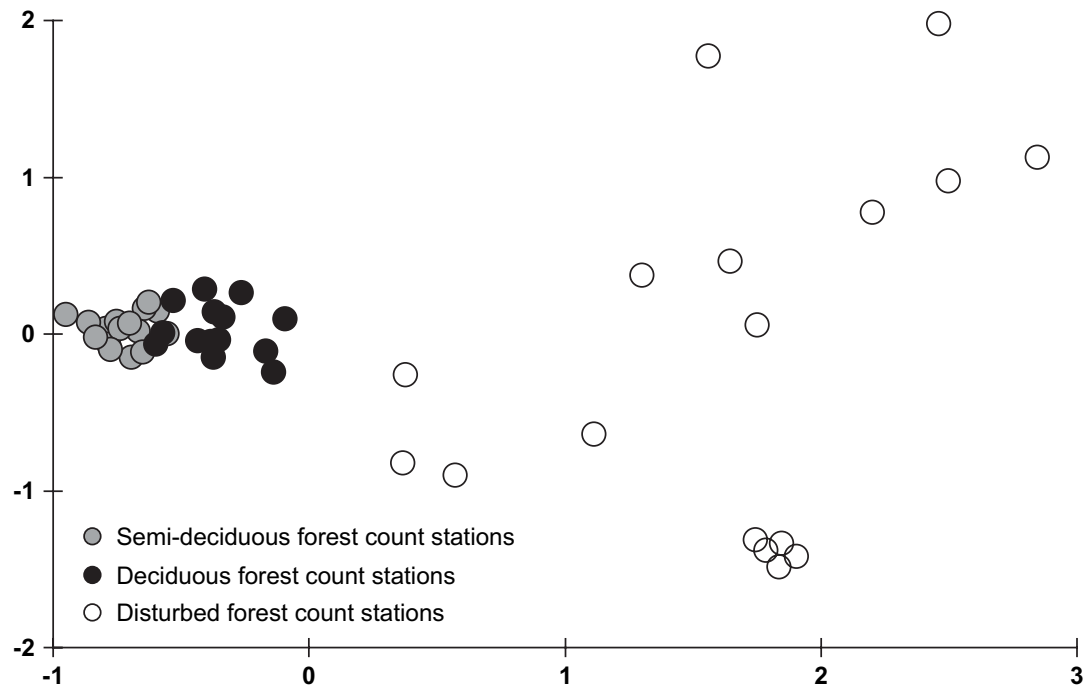

Figure 2. Two-dimensional ordination of bird communities (based on CA) of the three forest sites based on $\log ^{10}$-transformed maximum species abundances per point count station. The first two axes explained $51.3 \%$ and $25.3 \%$ of the variance, respectively.

variables were subsequently associated with bird species abundances per point count station using canonical correspondence analysis. Associations with vegetation structure clearly differed among bird species in the study area (Figure 3). Abundances of the majority of bird species were primarily associated with the condensed vegetation structure variables represented by axis $\mathrm{PC}_{1}$ (Figure 3; Monte-Carlo permutation test: $P<0.010)$. This PCI was most strongly correlated with vegetation structure variables that distinguished the disturbed forest from the undisturbed forests, i.e. density of large trees, density of small trees, diameter of larger trees, canopy height, and canopy cover).

Additionally, abundance of some species was associated with either axis $\mathrm{PC}_{2}$ or $\mathrm{PC}_{3}$, some species were positively correlated with herb cover whereas others were negatively correlated with herb cover (Figure 3; Monte-Carlo permutation test: $P<0.01$ ). These results indicate that vegetation structure variables which are related to anthropogenic habitat disturbance (either of $\mathrm{PC}_{1}, \mathrm{PC}_{2}$ or $\mathrm{PC}_{3}$ ) explain a significant part of the species-environment variation.

\section{Habitat preference categories}

Humid forest specialists $(n=48)$ were almost absent from the disturbed forest with only eight species ( $17 \%$ ) observed (see Appendix). Mean abundance of this group (all species pooled) was significantly highest in the semi-deciduous forest site (Table 2). Dry forest specialists $(n=14)$ showed the opposite pattern and showed lowest mean abundance in the semi-deciduous forest. All species representing this group were observed in the disturbed forest, whereas only eight $(57 \%)$ and five $(36 \%)$ species were observed in the deciduous forest and semi-deciduous forest, respectively. Mean abundance of dry forest specialists showed no difference between the disturbed forest and the deciduous forest (Table 2).

Species richness of forest generalists was most evenly distributed among the three forest types. This group was represented by 30 species in the deciduous forest, 28 species in the disturbed forest and 23 species in the semi-deciduous forest. Despite this evenly distributed species 


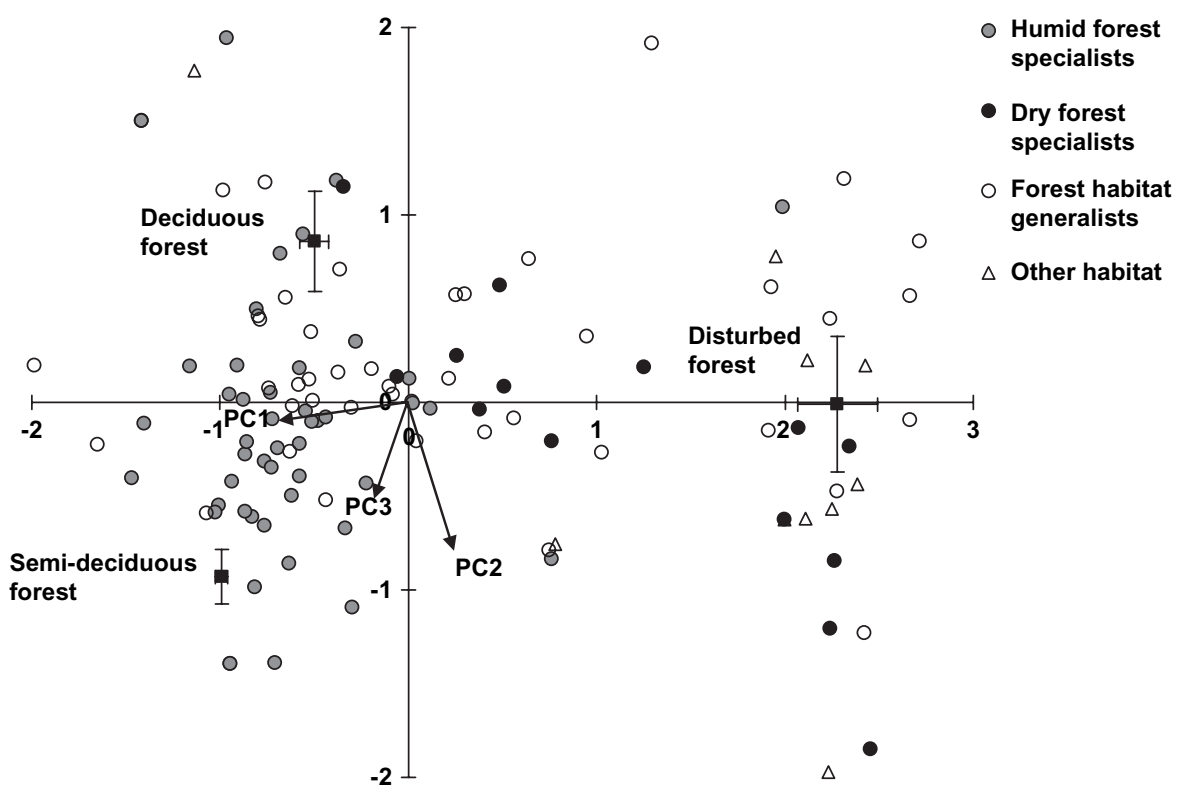

Figure 3. Two-dimensional ordination by CCA relating $\log ^{10}$-transformed bird species abundances to vegetation structure variables. Vegetation structure variables were condensed by PCA (see text) and are represented by the vectors $\mathrm{PC}_{1}, \mathrm{PC}_{2}$ and $\mathrm{PC}_{3}$. Only relationships between the first three PC vectors and dependent variables were significant (Monte-Carlo permutation test, $P<0.05$ ) and are shown. Species were a priori classified into habitat preference categories (listed in Appendix). Plotted forest sites represent the mean factor scores of the point count stations \pm SE.

richness, mean abundance of forest generalists $(n=43)$ differed significantly between the three study sites, and was highest in the deciduous forest and lowest in the disturbed forest (Table 2). Bird species associated with non-forest habitat $(n=10)$ were absent from the semi-deciduous forest, and only two species were observed in the deciduous forest (see Appendix).

The uneven distribution of the different habitat preference categories among the three study sites was supported by canonical correspondence analysis (Figure 3). Species of the different habitat preference categories showed different relationships with vegetation structure variables. Almost all humid forest specialists were positively correlated with PC 1 (representing vegetation structure indicative for undisturbed forest) and showed the highest clustering, suggesting highest habitat specificity among these species (Figure 3). On the contrary, dry forest specialists did not show such strong clustering, and species were either related to vegetation structure characteristic for the disturbed forest or deciduous forest. Forest generalists showed the greatest spread, indicating the lowest habitat specificity compared with species of the other groups. Although species of other habitats showed some spread, they all showed a distribution close to disturbed forest.

\section{Foraging guilds}

Bark-gleaning insectivores, ground dwelling species, understorey insectivores and canopy insectivores showed a significantly lower mean abundance in the disturbed forest compared to both undisturbed forest sites (Table 2). In contrast to these foraging guilds, only scrub insectivores and scrub frugi-granivores showed an opposite pattern (Table 2). No scrub insectivores 
Table 2. Mean abundance of the bird community in the three forest types in functional groups sorted by habitat affinity and foraging guild. Maximum number of individuals per point count station was used as a replicate. The total number of bird species per functional group (all count stations pooled) is listed between parentheses.

\begin{tabular}{|c|c|c|c|c|c|c|c|}
\hline \multirow[t]{2}{*}{ Functional group } & \multicolumn{3}{|c|}{ Mean abundance \pm SE per count station } & \multirow[t]{2}{*}{$P$} & \multicolumn{3}{|c|}{ Post-hoc tests } \\
\hline & Semi-deciduous forest & Deciduous forest & Disturbed Forest & & $\mathrm{S} \times \mathrm{DE}$ & S x DI & DE $\times$ DI \\
\hline \multicolumn{8}{|l|}{ Habitat affinity } \\
\hline Humid forest specialists $(n=48)$ & $23.9 \pm 1.1$ & $16.0 \pm 1.0$ & $3.9 \pm 0.5$ & $<0.001^{\mathrm{a}}$ & $* * *$ & $* * *$ & $* * *$ \\
\hline Dry forest specialists $(n=14)$ & $1.8 \pm 0.3$ & $5.6 \pm 0.8$ & $7.8 \pm 0.8$ & $<0.001^{\mathrm{b}}$ & ** & $* * *$ & ns \\
\hline Forest habitat generalists $(n=43)$ & $13.6 \pm 1.2$ & $19.2 \pm 1.5$ & $9.7 \pm 0.8$ & $<0.001^{\mathrm{a}}$ & ** & * & $* * *$ \\
\hline Other habitat $(n=10)$ & - & $0.4 \pm 0.3$ & $2.9 \pm 0.5$ & np & - & - & - \\
\hline \multicolumn{8}{|l|}{ Foraging guild } \\
\hline Canopy insectivores $(n=20)$ & $8.9 \pm 1.0$ & $9.6 \pm 1.0$ & $3.2 \pm 0.4$ & $<0.001^{b}$ & ns & $* * *$ & $* * *$ \\
\hline Canopy frugi-granivores $(n=19)$ & $5.4 \pm 1.0$ & $4.1 \pm 1.1$ & $2.6 \pm 0.6$ & $0.091^{\mathrm{a}}$ & - & - & - \\
\hline Canopy omnivores $(n=6)$ & $2.4 \pm 0.4$ & $3.6 \pm 0.7$ & $2.9 \pm 0.4$ & $0.279^{\mathrm{a}}$ & - & - & - \\
\hline Understory insectivores $(n=22)$ & $11.8 \pm 0.7$ & $11.6 \pm 0.9$ & $7.1 \pm 0.5$ & $<0.001^{\mathrm{a}}$ & $\mathrm{ns}$ & $* * *$ & $* * *$ \\
\hline Understory frugi-granivores $(n=8)$ & $3.1 \pm 0.4$ & $1.5 \pm 0.4$ & $1.4 \pm 0.3$ & $0.003^{\mathrm{a}}$ & * & $* *$ & ns \\
\hline Ground-dwelling species $(n=8)$ & $3.1 \pm 0.4$ & $4.0 \pm 0.4$ & $1.7 \pm 0.2$ & $<0.001^{\mathrm{a}}$ & ns & * & $* * *$ \\
\hline Bark-gleaning insectivores $(n=10)$ & $3.2 \pm 0.3$ & $4.5 \pm 0.4$ & $0.3 \pm 0.2$ & $<0.001^{\mathrm{a}}$ & * & $* * *$ & $* * *$ \\
\hline Nectarivores $(n=6)$ & $1.4 \pm 0.2$ & $1.6 \pm 0.4$ & $1.3 \pm 0.2$ & $0.661^{a}$ & ns & $\mathrm{ns}$ & ns \\
\hline Scrub insectivores $(n=6)$ & - & - & $2.3 \pm 0.4$ & $\mathrm{np}$ & - & - & - \\
\hline Scrub frugi-granivores $(n=7)$ & - & $0.7 \pm 0.4$ & $1.2 \pm 0.5$ & np & - & - & - \\
\hline
\end{tabular}

$P$ indicates result of comparison of mean abundance: ${ }^{a}$ one-way ANOVA, ${ }^{\mathrm{b}}$ Kruskal-Wallis test.

Asterisks indicate level of significant difference of post-hoc tests ( $\mathrm{S}$ DE, S x DI, DE x DI): ${ }^{*} P=<0.05 ;{ }^{* *} P=<0.01 ;{ }^{* * * P}<0.001$.

Other abbreviations: S: semi-deciduous forest; DE: deciduous forest; DI: disturbed forest; np: number of observations was too low to perform statistical test; ns: not significant. 
were observed in the undisturbed forest, and scrub frugi-granivores were absent from the semideciduous forest. Although mean abundance of the latter group was highest in the disturbed forest the difference was not significant. Abundance of carnivores (three species) was too low to perform any analysis.

\section{Discussion}

In the present study we found clear differences in bird community composition among the investigated forest types. Observed species richness and mean alpha diversity was considerable lower in the disturbed forest, whereas it differed only marginally between both undisturbed forest sites. This is further underlined by the high turnover in species composition between both undisturbed forest sites and the disturbed forest. Although differences in rarefied species richness were not significant between any of the three forests, this could most likely be explained by the significantly lowest species abundance of the bird community in the disturbed forest.

The majority of species only observed in the disturbed forest can be considered characteristic for dry lowland habitat (i.e. Pearly-vented Tody-Tyrant Hemitriccus margaritaceiventer, Black-capped Warbling-Finch Poospiza melanoleuca) or humid secondary habitat (i.e. Green-winged Saltator Saltator similis, Masked Yellowthroat Geothlypis aequinoctialis). Anthropogenic habitat disturbance most likely created novel habitat opportunities that are not present in undisturbed forests for these species, such as decreased canopy cover and artificial gaps. However, as a consequence, the disturbed forest most likely does not harbour habitat types characteristic for species of undisturbed forests. In the present study this is illustrated by the distribution of several species of Dendrocolaptidae, Furnariidae, Thraupidae and Tyrannidae that did not occur in the disturbed forest. Consequently, the bird community of the disturbed forest is represented by a depleted assemblage of bird species typical for (semi-) deciduous forest, augmented with species that apparently took advantage of human habitat disturbance.

Relations of bird species with vegetation structure variables support this observation. Various vegetation structure variables indicative of human habitat disturbance (i.e. canopy cover and height, density of large trees with a dbh of $>20 \mathrm{~cm}$ ) were negatively correlated with abundance of bird species characteristic for undisturbed forests in the disturbed forest. Additionally, coefficients of variation of various vegetation structure variables that can be related to human habitat disturbance (i.e. canopy cover and height, number of trees with a $\mathrm{dbh}$ of $<2 \mathrm{~cm}$, and total vegetation volume of shrub) suggest a more heterogeneous forest structure in the disturbed forest, and coincides with highest spatial turnover in species composition (beta diversity) within the disturbed forest. In accordance with results of studies in other tropical forests (e.g. Gascon et al. 1999, Waltert et al. 2004, Watson et al. 2004, Peh et al. 2005, Soh et al. 2006), the observations in the present study therefore suggest a negative effect of human habitat disturbance on a montane deciduous forest bird community.

Although there was a general negative influence of human habitat disturbance on the deciduous forest bird community, bird species were not affected equally. Humid forest specialists and some forest generalists showed strong sensitivity to human habitat disturbance (resulting in absence or reduced abundance in the disturbed forest), whereas dry forest specialists were not sensitive (resulting in higher species richness and abundance in the disturbed forest). Loss of intact and complex forest habitat due to human disturbance clearly restricts the distribution of the first two species groups in the study area. Among the negatively affected humid forest specialists were the restricted range species Bolivian Recurvebill Simoxenops striatus, classified as 'Vulnerable' by IUCN (IUCN 2004) and Yungas Manakin Chiroxiphia boliviana (Stattersfield et al. 1998). Since no large differences were observed in species richness and abundance of dry forest specialists between the disturbed forest and the undisturbed forests, human habitat 
disturbance most likely does not negatively influence distribution of these species in the investigated forests.

These differences in sensitivity to disturbance between specialists of different forest types could, at least in part, be explained by species' foraging guilds. Species that are dependent on the presence of tall trees (i.e. canopy insectivores and bark gleaning insectivores) and species associated with the microhabitat typical for intact forest (ground dwelling species) were disproportionately affected by human habitat disturbance. The decreased density of trees with a $\mathrm{dbh}>10 \mathrm{~cm}$ in the disturbed forest directly affected the former species, whereas altered microhabitat and constrained dispersal (as a result of fragmentation of particular habitats), most likely affected the latter group.

In addition, observed differences in habitat affinity/specificity between the species of the studied bird community, may suggest that species which primarily occur in deciduous forests have a higher resilience to human habitat disturbance compared to species that are restricted to semi-deciduous forests, possibly through adaptation of species of deciduous forest bird communities to a more temporal and spatial heterogeneous habitat.

\section{Limitations of the present study}

The present study was not spatially replicated in other forest regions, and lacks data on seasonality. Results and conclusions of the present study can therefore not be straight forwarded into generalisations on resilience of bird communities in human disturbed (semi-) deciduous forests and underlying mechanisms. Bird species may show different habitat utilisation depending on season, and there may be regional differences. However, the study area represents one of the last large pristine deciduous forest region in South America. Results therefore provide the first insights on how a South American tropical deciduous forest bird community can be affected by human disturbance in relation to habitat structure. Most tropical birds have year-round territories and sampling started with the onset of the major breeding season when movements of species are smallest and site fidelity is highest. It is therefore unlikely that the observed species-environment relationships have been affected to a large extent by the sampling period of the present study. However, since the results indicate the importance of this biogeographic area, further research is desired to explore the possible effect of seasonality and spatial differences on habitat utilization by deciduous forest birds.

\section{Conclusions}

The present study clearly indicates various effects of human habitat disturbance on avian community composition of a semi-deciduous and deciduous foothill forest in central Bolivia. Disturbance resulted in an impoverished bird community, and undisturbed forest is important for the survival of a number of forest specialist species. However, the results also suggest that sensitivity to disturbance varied among functional groups. Humid forest specialists were most vulnerable and showed the strongest decrease in disturbed forest, especially bark-gleaning insectivores, canopy insectivores, understorey insectivores and ground-dwelling species. On the contrary, some dry forest specialists that are characteristic of deciduous forests were relatively resilient to disturbance.

In conclusion, the present study indicates that conservation of deciduous forest remnants is important for a diverse montane bird community in the Andean foothills of Bolivia. Because various bird species typical for montane deciduous forests may also be able to survive in partly disturbed forests, conservation of these habitats seems still very worthwhile. This will increase the possibilities of protecting these bird communities in the future, especially since by now large pristine deciduous forests in Bolivia have practically disappeared. 


\section{Acknowledgements}

JA was financially supported by a grant of the IWP fund of the Radboud University Nijmegen, the Netherlands. SKH's research in the Refugio Los Volcanes was supported by the Deutsche Forschungsgemeinschaft and the Deutscher Akademischer Austauschdienst. Thanks to A. Schwiening for allowing us to work in the Refugio Los Volcanes. The people of Bermejo kindly provided permission to access the disturbed forest. JA thanks B. Hillmann for his company and assistance during part of the fieldwork. The personnel of the Asociación Armonía, Bolivia, provided logistic support.

\section{References}

Achard, F., Eva, H. D., Stibig, H. J., Mayaux, P., Gallego, J., Richards, T. and Malingreau, J. P. (2002) Determination of deforestation rates of the world's humid tropical forests. Science 297: 999-1002.

Andresen, E. (2005) Effects of season and vegetation type on community organization of dung beetles in a tropical dry forest. Biotropica 37: 291-300.

Beissinger, S. R., Steadman, E. C., Wohlgenant, T., Blate, G. and Zack, S. (1996) Null models for assessing ecosystem conservation priorities: threatened birds as titers of threatened ecosystems in South America. Conserv. Biol. 10: 1343-1352.

Bibby, C. J., Hill, D. A., Burgess, N. D. and Mustoe, S. (2000) Bird census techniques. Second edition. London: Academic Press.

BirdLife International (2000) Threatened birds of the world. Barcelona and Cambridge, UK: Lynx Edicions and BirdLife International.

Bullock, S. H., Mooney, H. A. and Medina, E. (eds.). (1995) Seasonally dry tropical forests. Cambridge, UK: Cambridge University Press.

Canterbury, G. E., Martin, T. E., Petit, D. R., Petit, L. J. and Bradford, D. F. (2000) Bird communities and habitat as ecological indicators of forest condition in regional monitoring. Conserv. Biol. 14: 544-558.

Chao, A., Chazdon, R. L, Colwell, R. K. and Shen, T. J. (2005) A new statistical approach for assessing similarity of species composition with incidence and abundance data. Ecol. Lett. 8: 148-159.

Colwell, R. K. (2005) EstimateS: statistical estimation of species richness and shared species from samples. Version 7.5.o. Persistent URL $<$ purl.oclc.org/estimates $>$.

Colwell, R. K., Mao, C. X. and Chang, J. (2004) Interpolating, extrapolating, and comparing incidence-based species accumulation curves. Ecology 85: 2717-2727.

del Hoyo, J., Elliott, A. and Sargatal, J. (eds.). (1992-2005) Handbook of the birds of the world. Vols. 1-10. Barcelona, Spain: Lynx Edicions.

Gascon, C., Lovejoy, T. E., Bierregaard, R. O., Malcolm, J. R., Stouffer, P. C., Vasconcelos, H. L., Laurance, W. F., Zimmerman, B., Tocher, M. and Borges, S. (1999) Matrix habitat and species richness in tropical forest remnants. Biol. Conserv. 91: 223-229.

Gotelli, N. J. and Colwell, R. K. (2001) Quantifying biodiversity: procedures and pitfalls in the measurement and comparison of species richness. Ecol. Lett. 4: 379391.

Hennesey, A. B., Herzog, S. K. and Sagot, F. (2003) Lista anotada de las aves de Bolivia. Quinta edición. Santa Cruz de la Sierra, Bolivia: Associación Armonía/ BirdLife International.

Herzog, S. K. and Kessler, M. (2002) Biogeography and composition of dry forest bird communities in Bolivia. J. Ornithol. 143: 172-204.

Herzog, S. K., Kessler, M. and Cahill, T. C. (2002) Estimating species richness of tropical bird communities from rapid assessment data. Auk 119: 749-769.

IUCN (2004) 2004 IUCN Red List of threatened species. Gland, Switzerland: IUCN. http://www.redlist.org. Accessed 18 January 2007. 
Janzen, D. H. (1988) Tropical dry forests, the most endangered major tropical ecosystem. Pp. 130-137 in E. O. Wilson, ed. Biodiversity. Washington, DC: National Academy Press.

Lee, T. M., Soh, M. C. K., Sodhi, N., Koh, L. P. and Lim, S. L.-H. (2004) Effects of habitat disturbance on mixed species bird flocks in a tropical sub-montane rainforest. Biol. Conserv. 122: 193-204.

Mayer, S. (2000) Birds of Bolivia 2.0 (CDROM). Westernieland, The Netherlands: Bird Songs International.

Mönkkönen, M. and Welsh, D. A. (1994) A biogeographical hypothesis on the effects of human caused landscape changes on the forest bird communities of Europe and North America. Ann. Zool. Fenn. 31: 61-70.

Parker, T. A., III, Gentry, A. H., Foster, R. B., Emmons, L. H. and Remsen, J. V., Jr. (1993) The lowland dry forests of Santa Cruz, Bolivia: a global conservation priority. RAP Working Papers 4. Washington, DC: Conservation International.

Peh, K. S.-H., de Jong, J., Sodhi, N. S., Lim, S. L.-H. and Yap, C. A.-M. (2005) Lowland rainforest avifauna and human disturbance: persistence of primary forest birds in selectively logged forests and mixedrural habitats of southern Peninsular Malaysia. Biol. Conserv. 123: 489-505.

Perry, A., Kessler, M. and Helme, N. (1997) Birds of the central Río Tuichi valley, with emphasis on dry forest, Parque Nacional Madidi, depto. La Paz, Bolivia. Pp. 557-576 in J. V. Remsen, Jr., ed. Studies in Neotropical ornithology honoring Ted Parker. Ornithol. Monogr. 48. Washington.

Petit, L. J. and Petit, D. R. (2003) Evaluating the importance of human-modified lands for Neotropical bird conservation. Conserv. Biol. 17: 687-694.

Ridgely, R. S. and Tudor, G. (1989, 1994) The birds of South America. Vols. 1 and 2. Oxford, UK: Oxford University Press.

Sánchez-Azofeifa, G. A., Kalacska, M., Quesada, M., Calvo-Alvarado, J. C., Nassar, J.
M. and Rodríguez, J. P. (2005) Need for integrated research for a sustainable future in tropical dry forests. Conserv. Biol. 19: 285-286.

Schmiegelow, F. K. A., Machtans, C. S. and Hannon, S. J. (1997) Are boreal birds resilient to forest fragmentation? An experimental study of short-term community responses. Ecology 78: 1914-1932.

Soh, M. C. K., Sodhi, N. S. and Lim, S. L.-H. (2006) High sensitivity of montane bird communities to habitat disturbance in Peninsular Malaysia. Biol. Conserv. 129, 149166.

Stattersfield, A. J., Crosby, M. J., Long, A. J. and Wege, D. C. (1998) Endemic bird areas in the world: priorities for biodiversity conservation. Cambridge, UK: BirdLife International.

Tejeda-Cruz, C. and Sutherland, W. J. (2005) Cloud forest bird responses to unusually severe storm damage. Biotropica 37: 88-95.

Ter Braak, C. J. F. (1995) Ordination. Pp. 91173 in R. H. G. Jongman, C. J. F. Ter Braak and O. F. R. Van Tongeren, eds. Data analysis in community and landscape ecology. Cambridge, UK: Cambridge University Press.

Thiollay, J. (1997) Disturbance, selective logging and bird diversity: a Neotropical forest study. Biodivers. Conserv. 6: 1155-1173.

Waltert, M., Mardiastuti, A. and Mühlenberg, M. (2004) Effects of land use on bird species richness in Sulawesi, Indonesia. Conserv. Biol. 18: 1339-1346.

Watson, J. E. M., Whittaker, R. J. and Dawson, T. P. (2004) Habitat structure and proximity to forest edge affect the abundance and distribution of forest-dependent birds in tropical coastal forests of southeastern Madagascar. Biol. Conserv. 120: $311-327$.

Woltmann, S. (2003) Bird community responses to disturbance in a forestry concession in lowland Bolivia. Biodivers. Conserv. 12: 1921-1936. 
JOB ABEN*, MARTIJN DORENBOSCH, ALFONS J. P. SMOLDERS, GERARD VAN DER VELDE

Department of Animal Ecology and Ecophysiology, Institute for Water and Wetland Research, Faculty of Science, Radboud University Nijmegen, Toernooiveld 1, Nijmegen, 6525 ED, The Netherlands.

\section{SEBASTIAN K. HERZOG}

Asociación Armonía - BirdLife International, Casilla 3566, Santa Cruz de la Sierra, Bolivia, and Institut für Vogelforschung 'Vogelwarte Helgoland', An der Vogelwarte 21, 26386 Wilhelmshaven, Germany.

*Author for correspondence.e-mail: job.aben@gmail.com

Received 6 June 2007; revision accepted 19 February 2008

Appendix. Frequency of occurrence (expressed as the proportion of sampling points per habitat a species has been observed) of bird species observed in the three habitat types.

Species were classified a priori according to habitat preference (HP): dry forest specialists (D); humid forest specialists $(\mathrm{H})$; forest habitat generalists $(\mathrm{G})$; and species of other habitat $(\mathrm{O})$. Species were classified in the following foraging guilds $(\mathrm{FG})$ : canopy insectivore $(\mathrm{CI})$, frugi-granivore $(\mathrm{CF})$ or omnivore (CO); understorey insectivore (UI) or frugi-granivore (UF); ground dwelling species (G); bark-gleaning insectivore (B); nectarivore $(\mathrm{N})$; scrub insectivore (SI) or frugi-granivore (SF). Nomenclature follows Hennessey et al. (2003). ${ }^{1}$ Restricted-range species (Stattersfield et al. 1998); ${ }^{2}$ Species listed as 'Vulnerable' (IUCN 2004).

\begin{tabular}{|c|c|c|c|c|c|c|}
\hline \multirow[t]{2}{*}{ Species } & \multirow[t]{2}{*}{ Common name } & \multirow[t]{2}{*}{$\mathrm{HP}$} & \multirow[t]{2}{*}{ FG } & \multicolumn{3}{|c|}{ Frequency of occurrence } \\
\hline & & & & $\begin{array}{l}\text { Semi- } \\
\text { deciduous }\end{array}$ & Deciduous & Disturbed \\
\hline \multicolumn{7}{|l|}{ Tinamidae } \\
\hline Tinamus tao & Gray Tinamou & $\mathrm{H}$ & G & 0.25 & 0.36 & 0.00 \\
\hline Crypturellus obsoletus & Brown Tinamou & $\mathrm{H}$ & G & 0.63 & 0.21 & 0.00 \\
\hline C. tataupa & Tataupa Tinamou & $\mathrm{D}$ & G & 0.00 & 0.50 & 0.82 \\
\hline \multicolumn{7}{|l|}{ Cracidae } \\
\hline Ortalis guttata & Speckled Cachalaca & G & $\mathrm{CF}$ & 0.00 & 0.00 & 0.06 \\
\hline \multicolumn{7}{|l|}{ Odontophoridae } \\
\hline Odontophorus speciosus & $\begin{array}{l}\text { Rufous-breasted } \\
\text { Wood-Quail }\end{array}$ & $\mathrm{H}$ & G & 0.13 & 0.00 & 0.00 \\
\hline \multicolumn{7}{|l|}{ Accipitridae } \\
\hline Accipiter striatus & Sharp-shinned Hawk & G & $\mathrm{C}$ & 0.00 & 0.00 & 0.18 \\
\hline \multicolumn{7}{|l|}{ Columbidae } \\
\hline Columba plumbea & Plumbeous Pigeon & $\mathrm{H}$ & $\mathrm{CF}$ & 0.75 & 0.79 & 0.47 \\
\hline Leptotila megalura & Large-tailed Dove & G & G & 0.50 & 0.93 & 0.35 \\
\hline \multicolumn{7}{|l|}{ Psittacidae } \\
\hline Pyrrhura molinae & Green-cheeked Parakeet & G & $\mathrm{CF}$ & 0.19 & 0.36 & 0.12 \\
\hline Aratinga mitrata & Mitred Parakeet & G & CF & 0.00 & 0.21 & 0.00 \\
\hline
\end{tabular}


Appendix. Continued.

\begin{tabular}{|c|c|c|c|c|c|c|}
\hline \multirow[t]{2}{*}{ Species } & \multirow[t]{2}{*}{ Common name } & \multirow[t]{2}{*}{ HP } & \multirow[t]{2}{*}{ FG } & \multicolumn{3}{|c|}{ Frequency of occurrence } \\
\hline & & & & $\begin{array}{l}\text { Semi- } \\
\text { deciduous }\end{array}$ & Deciduous & Disturbed \\
\hline Brotogeris chiriri & Yellow-chevroned Parakeet & G & $\mathrm{CF}$ & 0.00 & 0.00 & 0.06 \\
\hline Amazona aestiva & Blue-fronted Parrot & $\mathrm{D}$ & $\mathrm{CF}$ & 0.19 & 0.00 & 0.29 \\
\hline \multicolumn{7}{|l|}{ Cuculidae } \\
\hline Piaya cayana & Squirrel Cuckoo & G & $\mathrm{CI}$ & 0.00 & 0.21 & 0.12 \\
\hline Crotophaga ani & Smooth-billed Ani & $\mathrm{O}$ & SI & 0.00 & 0.00 & 0.12 \\
\hline Guira guira & Guira Cuckoo & $\mathrm{O}$ & SI & 0.00 & 0.00 & 0.12 \\
\hline Tapera naevia & Striped Cuckoo & $\mathrm{O}$ & SI & 0.00 & 0.00 & 0.06 \\
\hline \multicolumn{7}{|l|}{ Strigidae } \\
\hline Glaucidium parkeri & Subtropical Pygmy-Owl & $\mathrm{H}$ & $\mathrm{C}$ & 0.06 & 0.00 & 0.00 \\
\hline G. brasilianum & Ferruginous Pygmy-Owl & G & $\mathrm{C}$ & 0.06 & 0.00 & 0.00 \\
\hline \multicolumn{7}{|l|}{ Trochilidae } \\
\hline Phaethornis pretrei & Planalto Hermit & $\mathrm{O}$ & $\mathrm{N}$ & 0.00 & 0.00 & 0.12 \\
\hline P. malaris & Great-billed Hermit & $\mathrm{H}$ & $\mathrm{N}$ & 0.69 & 0.57 & 0.06 \\
\hline Colibri coruscans & Sparkling Violetear & $\mathrm{O}$ & $\mathrm{N}$ & 0.00 & 0.14 & 0.00 \\
\hline Chlorostilbon aureoventris & Glittering-bellied Emerald & $\mathrm{D}$ & $\mathrm{N}$ & 0.00 & 0.00 & 0.65 \\
\hline Thalurania furcata & Fork-tailed Woodnymph & $\mathrm{H}$ & $\mathrm{N}$ & 0.56 & 0.14 & 0.12 \\
\hline Chrysuronia oenone & Golden-tailed Sapphire & $\mathrm{H}$ & $\mathrm{N}$ & 0.13 & 0.00 & 0.00 \\
\hline Amazilia chionogaster & $\begin{array}{l}\text { White-bellied } \\
\text { Hummingbird }\end{array}$ & $\mathrm{D}$ & $\mathrm{N}$ & 0.44 & 0.64 & 0.24 \\
\hline \multicolumn{7}{|l|}{ Trogonidae } \\
\hline Trogon curucui & Blue-crowned Trogon & G & $\mathrm{CI}$ & 0.56 & 0.50 & 0.18 \\
\hline \multicolumn{7}{|l|}{ Momotidae } \\
\hline Momotus momota & Blue-crowned Motmot & G & $\mathrm{UI}$ & 0.00 & 0.07 & 0.00 \\
\hline \multicolumn{7}{|l|}{ Buconnidae } \\
\hline Nystalus chacuru & White-eared Puffbird & $\mathrm{D}$ & SI & 0.00 & 0.00 & 0.06 \\
\hline Malacoptila fulvogularis & Black-streaked Puffbird & $\mathrm{H}$ & UI & 0.06 & 0.07 & 0.00 \\
\hline \multicolumn{7}{|l|}{ Ramphastidae } \\
\hline Aulacorhynchus derbianus & Chestnut-tipped Toucanet & $\mathrm{H}$ & $\mathrm{CF}$ & 0.13 & 0.00 & 0.00 \\
\hline Pteroglossus castanotis & Chestnut-eared Aracari & G & $\mathrm{CF}$ & 0.00 & 0.00 & 0.06 \\
\hline \multicolumn{7}{|l|}{ Picidae } \\
\hline Picumnus dorbignyanus & Ocellated Piculet & G & B & 0.00 & 0.14 & 0.06 \\
\hline Melanerpes cruentatus & Yellow-tufted Woodpecker & $\mathrm{H}$ & B & 0.00 & 0.00 & 0.06 \\
\hline Piculus rubiginosus & Golden-olive Woodpecker & G & B & 0.06 & 0.00 & 0.00 \\
\hline Campephilus rubricollis & Red-necked Woodpecker & $\mathrm{H}$ & B & 0.19 & 0.14 & 0.00 \\
\hline C. melanoleucos & $\begin{array}{l}\text { Crimson-crested } \\
\text { Woodpecker }\end{array}$ & G & B & 0.00 & 0.43 & 0.06 \\
\hline \multicolumn{7}{|l|}{ Dendrocolaptidae } \\
\hline Sittasomus griseicapillus & Olivaceous Woodcreeper & G & B & 0.75 & 0.93 & 0.06 \\
\hline Dendrocolaptes picumnus & Black-banded Woodcreeper & G & B & 0.13 & 0.21 & 0.00 \\
\hline Xiphorhynchus ocellatus & Ocellated Woodcreeper & $\mathrm{H}$ & B & 0.88 & 0.86 & 0.00 \\
\hline $\begin{array}{l}\text { Campylorhamphus } \\
\text { trochilirostris }\end{array}$ & Red-billed Scythebill & G & $\mathrm{B}$ & 0.00 & O.14 & 0.00 \\
\hline \multicolumn{7}{|l|}{ Furnaridae } \\
\hline Synallaxis frontalis & Sooty-fronted Spinetail & $\mathrm{D}$ & UI & 0.00 & 0.00 & 0.29 \\
\hline S. scutata & Ochre-cheeked Spinetail & $\mathrm{D}$ & UI & 0.38 & 0.64 & 0.47 \\
\hline Simoxenops striatus ${ }^{1,2}$ & Bolivian Recurvebill & $\mathrm{H}$ & $\mathrm{UI}$ & 0.06 & 0.14 & 0.00 \\
\hline Philydor rufum & $\begin{array}{l}\text { Buff-fronted } \\
\text { Foliagegleaner }\end{array}$ & $\mathrm{H}$ & $\mathrm{CI}$ & 0.75 & 0.36 & 0.00 \\
\hline
\end{tabular}


Appendix. Continued.

\begin{tabular}{|c|c|c|c|c|c|c|}
\hline \multirow[t]{2}{*}{ Species } & \multirow[t]{2}{*}{ Common name } & \multirow[t]{2}{*}{$\mathrm{HP}$} & \multirow[t]{2}{*}{ FG } & \multicolumn{3}{|c|}{ Frequency of occurrence } \\
\hline & & & & $\begin{array}{l}\text { Semi- } \\
\text { deciduous }\end{array}$ & Deciduous & Disturbed \\
\hline Sclerurus albigularis & Gray-throated Leaftosser & $\mathrm{H}$ & G & 0.13 & 0.21 & 0.00 \\
\hline Xenops rutilans & Streaked Xenops & G & B & 0.69 & 0.79 & 0.00 \\
\hline \multicolumn{7}{|l|}{ Thamnophilidae } \\
\hline Batara cinerea & Giant Antshrike & G & UI & 0.00 & 0.00 & 0.12 \\
\hline Thamnophilus palliatus & $\begin{array}{l}\text { Chestnut-backed } \\
\text { Antshrike }\end{array}$ & $\mathrm{H}$ & $\mathrm{UI}$ & 0.00 & 0.43 & 0.00 \\
\hline Thamnophilus caerulescens & Variable Antshrike & G & UI & 0.00 & 0.07 & 0.53 \\
\hline Dysithamnus mentalis & Plain Antvireo & G & UI & 0.81 & 0.50 & 0.00 \\
\hline Herpsilochmus atricapillus & Black-capped Antwren & G & $\mathrm{CI}$ & 0.75 & 0.79 & 0.82 \\
\hline \multicolumn{7}{|l|}{ Formicaridae } \\
\hline \multicolumn{7}{|l|}{ Conopophagidae } \\
\hline $\begin{array}{l}\text { Conopophaga ardesiaca } \\
\text { Rhinocryptidae }\end{array}$ & Slaty Gnateater & $\mathrm{H}$ & $\mathrm{UI}$ & 0.75 & 0.86 & 0.18 \\
\hline \multicolumn{7}{|l|}{ Tyrannidae } \\
\hline Phyllomyias burmeisteri & Rough-legged Tyrannulet & $\mathrm{H}$ & $\mathrm{CO}$ & 0.00 & 0.07 & 0.00 \\
\hline P. sclateri & Sclater's Tyrannulet & G & $\mathrm{CI}$ & 0.50 & 0.64 & 0.00 \\
\hline Camptostoma obsoletum & $\begin{array}{l}\text { Southern Beardless- } \\
\text { Tyrannulet }\end{array}$ & $\mathrm{D}$ & $\mathrm{CI}$ & 0.13 & 0.50 & 0.35 \\
\hline Phylloscartes ophthalmicus & Marble-faced Bristle-Tyrant & $\mathrm{H}$ & $\mathrm{CI}$ & 0.19 & 0.00 & 0.00 \\
\hline Mionectes macconnelli & McConnell's Flycatcher & $\mathrm{H}$ & UI & 0.50 & 0.00 & 0.00 \\
\hline Leptopogon amaurocephalus & Sepia-capped Flycatcher & G & UI & 0.06 & 0.07 & 0.00 \\
\hline L. superciliaris & Slaty-capped Flycatcher & $\mathrm{H}$ & UI & 0.50 & 0.14 & 0.00 \\
\hline Myiornis albiventris & $\begin{array}{l}\text { White-bellied Pygmy- } \\
\text { Tyrant }\end{array}$ & $\mathrm{H}$ & $\mathrm{CI}$ & 0.00 & 0.21 & 0.00 \\
\hline Hemitriccus margaritaceiventer & Pearly-vented Tody-Tyrant & $\mathrm{D}$ & $\mathrm{UI}$ & 0.00 & 0.07 & 0.94 \\
\hline Tolmomyias sulphurescens & Yellow-olive Flycatcher & G & $\mathrm{CI}$ & 0.50 & 0.79 & 0.06 \\
\hline Platyrinchus mystaceus & White-throated Spadebill & $\mathrm{H}$ & UI & 0.13 & 0.00 & 0.00 \\
\hline Pyrrhomyias cinnamomea & Cinnamon Flycatcher & $\mathrm{H}$ & $\mathrm{CI}$ & 0.06 & 0.00 & 0.00 \\
\hline Myiodynastes chrysocephalus & Golden-crowned Flycatcher & $\mathrm{H}$ & $\mathrm{CI}$ & 0.44 & 0.07 & 0.00 \\
\hline M. maculatus & Streaked Flycatcher & G & $\mathrm{CI}$ & 0.06 & 0.00 & 0.00 \\
\hline Casiornis rufa & Rufous Casiornis & $\mathrm{D}$ & $\mathrm{CI}$ & 0.00 & 0.64 & 0.24 \\
\hline Myiarchus tuberculifer & Dusky-capped Flycatcher & G & $\mathrm{CI}$ & 0.25 & 0.64 & 0.00 \\
\hline M. cephalotes & Pale-edged Flycatcher & $\mathrm{H}$ & $\mathrm{CI}$ & 0.19 & 0.14 & 0.00 \\
\hline Tityra semifasciata & Masked Tityra & $\mathrm{H}$ & $\mathrm{CI}$ & 0.25 & 0.00 & 0.00 \\
\hline $\begin{array}{l}\text { Pachyramphus viridis } \\
\text { Pipridae }\end{array}$ & Green-backed Becard & G & $\mathrm{CI}$ & 0.00 & 0.07 & 0.00 \\
\hline Chiroxiphia boliviana $^{I}$ & Yungas Manakin & $\mathrm{H}$ & UF & 0.81 & 0.07 & 0.00 \\
\hline Pipritis chloris & Wing-barred Piprites & $\mathrm{H}$ & $\mathrm{CF}$ & 0.00 & 0.07 & 0.00 \\
\hline \multicolumn{7}{|l|}{ Vireonidae } \\
\hline Cyclarhis gujanensis & $\begin{array}{l}\text { Rufous-browed } \\
\text { Peppershrike }\end{array}$ & G & $\mathrm{CI}$ & 0.19 & 0.21 & 0.41 \\
\hline \multicolumn{7}{|l|}{ Corvidae } \\
\hline Cyanocorax cyanomelas & Purplish Jay & G & $\mathrm{CO}$ & 0.25 & 0.43 & 0.47 \\
\hline $\begin{array}{l}\text { C. chrysops } \\
\text { Troglodytidae }\end{array}$ & Plush-crested Jay & $\mathrm{D}$ & $\mathrm{CO}$ & 0.31 & 0.79 & 0.59 \\
\hline Thryothorus genibarbis & Moustached Wren & $\mathrm{H}$ & UI & 0.69 & 0.86 & 0.47 \\
\hline
\end{tabular}


Appendix. Continued.

\begin{tabular}{|c|c|c|c|c|c|c|}
\hline \multirow[t]{2}{*}{ Species } & \multirow[t]{2}{*}{ Common name } & \multirow[t]{2}{*}{ HP } & \multirow[t]{2}{*}{ FG } & \multicolumn{3}{|c|}{ Frequency of occurrence } \\
\hline & & & & $\begin{array}{l}\text { Semi- } \\
\text { deciduous }\end{array}$ & Deciduous & Disturbed \\
\hline \multicolumn{6}{|l|}{ Turdidae } & 0.71 \\
\hline Turdus nigriceps & Slaty Thrush & $\mathrm{H}$ & UF & 0.56 & 0.14 & 0.24 \\
\hline T. rufiventris & Rufous-bellied Thrush & G & $\mathrm{CI}$ & 0.13 & 0.64 & 0.29 \\
\hline T. amaurochalinus & Creamy-bellied Thrush & G & $\mathrm{CI}$ & 0.00 & 0.00 & 0.24 \\
\hline T. albicollis & White-necked Robin & $\mathrm{H}$ & UF & 0.81 & 0.36 & 0.00 \\
\hline \multicolumn{7}{|l|}{ Thraupidae } \\
\hline Trichothraupis melanops & Black-goggled Tanager & G & $\mathrm{UI}$ & 0.88 & 0.79 & 0.12 \\
\hline Ramphocelus carbo & Silver-beaked Tanager & $\mathrm{O}$ & SF & 0.00 & 0.07 & 0.00 \\
\hline Thraupis sayaca & Sayaca Tanager & G & $\mathrm{CF}$ & 0.00 & 0.00 & 0.24 \\
\hline T. palmarum & Palm Panager & $\mathrm{H}$ & $\mathrm{CF}$ & 0.25 & 0.00 & 0.00 \\
\hline Anisognathus somptuosus & $\begin{array}{l}\text { Blue-winged } \\
\text { Mountain-Tanager }\end{array}$ & $\mathrm{H}$ & $\mathrm{CF}$ & 0.06 & 0.00 & 0.00 \\
\hline Hemithraupis guira & Guira Tanager & G & $\mathrm{CI}$ & 0.00 & 0.36 & 0.00 \\
\hline Chlorospingus ophthalmicus & Common Bush-Tanager & $\mathrm{H}$ & $\mathrm{CO}$ & 0.25 & 0.07 & 0.00 \\
\hline Piranga leucoptera & White-winged Tanager & $\mathrm{H}$ & $\mathrm{CI}$ & 0.63 & 0.43 & 0.00 \\
\hline Euphonia chlorotica & Purple-throated Euphonia & G & $\mathrm{CF}$ & 0.31 & 0.36 & 0.18 \\
\hline E. laniirostris & Thick-billed Euphonia & $\mathrm{H}$ & $\mathrm{CF}$ & 0.13 & 0.00 & 0.00 \\
\hline E. cyanocephala & Golden-rumped Euphonia & $\mathrm{H}$ & $\mathrm{CF}$ & 0.00 & 0.36 & 0.00 \\
\hline E. mesochrysa & Bronze-green Euphonia & $\mathrm{H}$ & $\mathrm{CF}$ & 0.13 & 0.00 & 0.00 \\
\hline Chlorophonia cyanea & Blue-naped Chlorophonia & $\mathrm{H}$ & $\mathrm{CF}$ & 0.81 & 0.14 & 0.00 \\
\hline \multicolumn{7}{|l|}{ Emberizidae } \\
\hline Poospiza melanoleuca & $\begin{array}{l}\text { Black-capped } \\
\text { Warbling-Finch }\end{array}$ & $\mathrm{D}$ & SF & 0.00 & 0.00 & 0.29 \\
\hline Sporophila caerulescens & Double-collared Seedeater & $\mathrm{O}$ & SF & 0.00 & 0.00 & 0.12 \\
\hline Tiaris obscura & Dull-colored Grassquit & G & SF & 0.00 & 0.00 & 0.12 \\
\hline Arremon flavirostris & Saffron-billed Sparrow & $\mathrm{D}$ & G & 0.00 & 0.21 & 0.06 \\
\hline Coryphospingus cucullatus & Red-crested Finch & $\mathrm{D}$ & SF & 0.00 & 0.00 & 0.06 \\
\hline \multicolumn{7}{|l|}{ Cardinalidae } \\
\hline Pheucticus aureoventris & Black-backed Grosbeak & G & SF & 0.00 & 0.00 & 0.18 \\
\hline Saltator maximus & Buff-throated Saltator & $\mathrm{H}$ & $\mathrm{CF}$ & 0.00 & 0.07 & 0.00 \\
\hline S. similis & Green-winged Saltator & G & $\mathrm{CF}$ & 0.00 & 0.00 & 0.29 \\
\hline \multicolumn{7}{|l|}{ Parulidae } \\
\hline Parula pitiayumi & Tropical Parula & G & $\mathrm{CI}$ & 0.88 & 0.93 & 0.41 \\
\hline Geothlypis aequinoctialis & Masked Yellowthroat & $\mathrm{O}$ & SI & 0.00 & 0.00 & 0.53 \\
\hline Myioborus miniatus & Slate-throated Redstart & $\mathrm{H}$ & $\mathrm{CI}$ & 0.56 & 0.00 & 0.00 \\
\hline Basileuterus bivittatus & Two-banded Warbler & $\mathrm{H}$ & UI & 1.00 & 1.00 & 1.00 \\
\hline \multicolumn{7}{|l|}{ Icteridae } \\
\hline Psarocolius atrovirens & Dusky-green Oropendola & $\mathrm{H}$ & $\mathrm{CO}$ & 0.19 & 0.29 & 0.00 \\
\hline P. decumanus & Crested Oropendola & G & $\mathrm{CO}$ & 0.50 & 0.36 & 0.47 \\
\hline Gnorimopsar chopi & Chopi Blackbird & $\mathrm{O}$ & SF & 0.00 & 0.00 & 0.18 \\
\hline \multicolumn{7}{|l|}{ Fringillidae } \\
\hline Carduelis magellanica & Hooded Siskin & $\mathrm{O}$ & SF & 0.00 & 0.21 & 0.00 \\
\hline
\end{tabular}

